\title{
Meta-analysis to assess the effectiveness of topically used vancomycin in reducing sternal wound infections after cardiac surgery
}

\author{
Mariusz Kowalewski, MD, ${ }^{\mathrm{a}, \mathrm{b}}$ Giuseppe Maria Raffa, MD, ${ }^{\mathrm{c}}$ Krzysztof Aleksander Szwed, MD, ${ }^{\mathrm{d}}$ and \\ Lech Anisimowicz, MD, PhD, ${ }^{a}$ Bydgoszcz, Poland, and Palermo, Italy
}

\footnotetext{
From the ${ }^{\mathrm{a}}$ Department of Cardiac Surgery, Dr Antoni Jurasz Memorial University Hospital; ${ }^{\mathrm{b}}$ Department of Hygiene, Epidemiology and Ergonomics, Division of Ergonomics and Physical Effort, and ${ }^{\mathrm{d}}$ Department of Clinical Neuropsychology, Collegium Medicum UMK, Bydgoszcz, Poland; and ${ }^{\mathrm{c}}$ Department for the Treatment and Study of Cardiothoracic Diseases and Cardiothoracic Transplantation, IRCCS-ISMETT (Istituto Mediterraneo per I Trapianti e Terapie ad alta specializzazione), Palermo, Italy.

Disclosures: Authors have nothing to disclose with regard to commercial support.

Received for publication Jan 21, 2017; revisions received May 5, 2017; accepted for publication June 4, 2017; available ahead of print July 1, 2017.

Address for reprints: Mariusz Kowalewski, MD, Department of Cardiac Surgery, Dr Antoni Jurasz Memorial University Hospital, Maria Curie Sklodowska Str 9., Bydgoszcz 85-094, Poland (E-mail: kowalewskimariusz@ gazeta.pl).

J Thorac Cardiovasc Surg 2017;154:1320-3

0022-5223/\$36.00

Copyright $($ C 2017 by The American Association for Thoracic Surgery

http://dx.doi.org/10.1016/j.jtcvs.2017.06.004
}

Supplemental material is available online.

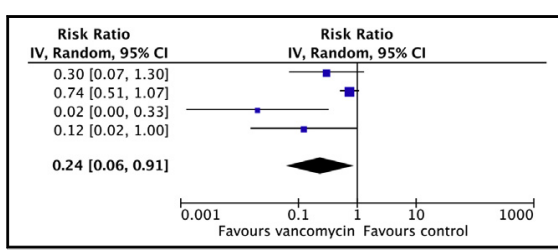

Reduction of risk for developing sternal wound infections with topically used vancomycin.

Central Message

With results concordant with recent expert consensus on the prevention and management of sternal wound infections (SWIs), a current meta-analysis shows topical vancomycin significantly reduces the risk of SWI.

See Editorial Commentary page 1324.
Deep sternal wound infections (DSWIs), although relatively rare, are associated with increased morbidity and mortality rates and decreased long-term life expectancy after cardiac surgery procedures. ${ }^{1}$ Although the role of intravenous antibiotic prophylaxis and strict intraoperative glycemic control is beyond doubt, whether additional topically administered antibiotics may further reduce the incidence of DSWI remains a subject of fierce debate. A recent expert consensus review on the prevention and management of sternal wound infections (SWIs) ${ }^{2}$ for the first time assigned a Class I Recommendation; Level of Evidence $=\mathrm{B}$ for topical antibiotics to be applied to the cut edges of the sternum on opening and before closing all cardiac surgical procedures involving a sternotomy, as they been found to significantly reduce the incidence of SWIs. The aforementioned statement primarily was driven by several reports of excellent results achieved with implantable gentamicin-collagen sponges ${ }^{3,4}$ and vancomycin paste administered topically to the sternal edges. 5 ,E1,E2

One recent study, ${ }^{\mathrm{E} 3}$ in contrast to previous reports, demonstrated that vancomycin paste neither reduced the incidence of DSWI nor was its use was a negative predictor of DSWI in a multivariate analyses accounting for body mass index $>30 \mathrm{~kg} / \mathrm{m}^{2}$, New York Heart Association Class IV, or Society of Thoracic Surgeons DSWI Risk Index. Given the highest potential of this study to guide decision making because of the number of patients involved, we performed a systematic review and meta-analysis of studies assessing topical use of vancomycin in reducing the incidence of SWIs after cardiac surgery.

A meta-analysis was performed in accordance to Preferred Reporting Items for Systematic Reviews and meta-analyses statement. ${ }^{\mathrm{E}}$ Major online databases (PubMed, MEDLINE, EMBASE, CENTRAL, Web of Science) as well as abstracts from major cardiothoracic surgery societies' meetings were screened for inclusion of relevant reports until December 31, 2016. Keywords used were "vancom*cin; -paste, -gel, -ointment, -slurry"; "topical*-, local*- vancom*cin"; "vancom*cin AND stern*"; "vancom*cin AND mediastin*." The search process was conducted by 2 reviewers (M.K. and G.M.R.); any divergences were resolved by a third reviewer (L.A.). Studies were considered eligible when comparing prophylactic topically administered vancomycin-based therapy versus no vancomycin/placebo in the setting of heart surgery performed via median sternotomy. Endpoints assessed were any SWIs, DSWIs, and superficial sternal wound infection (SSWIs). Risk ratio (RR) and 95\% confidence intervals (CIs) served as primary statistics. Data were pooled in the meta-analysis via the DerSimonian and Laird random effects model. Data were analyzed at reported follow-ups. Publication bias was assessed by constructing a funnel plot in which $\operatorname{logRR}$ was plotted against standard error. $P$ values were significant if less than or equal to .05. 
TABLE 1. Studies and patients' baseline characteristics

\begin{tabular}{|c|c|c|c|c|}
\hline Study & $\begin{array}{l}\text { Hamman and colleagues, } \\
\mathbf{2 0 1 4}^{\mathrm{E} 8} \\
\end{array}$ & Lander and colleagues, 2016 $^{\mathrm{E} 3}$ & Lazar and colleagues, $2014^{5}$ & $\begin{array}{l}\text { Vander Salm and colleagues, } \\
1989^{\mathrm{E} 7} \\
\end{array}$ \\
\hline Type of study & Retrospective & Retrospective & Retrospective & $\mathrm{RCT}$ \\
\hline Adjustments & Propensity score* & No & Propensity matching $\dagger$ & NA \\
\hline No. patients & 548 vs 1318 & 4997 vs 9495 & 1075 vs 2190 & 223 vs 193 \\
\hline Surgery & $\begin{array}{l}\text { CABG } 62.6 \% \text { vs } 74.2 \% \ddagger \\
\text { CABG }+ \text { valve } 16.6 \% \text { vs } 13.1 \% \\
\text { Isolated valve } 20.8 \% \text { vs } 12.8 \%\end{array}$ & $\begin{array}{l}\text { CABG } 36.2 \% \text { vs } 36.8 \% \\
\text { CABG + valve } 20.2 \% \text { vs } 18.7 \% \\
\text { Isolated valve } 43.6 \% \text { vs } 44.5 \%\end{array}$ & $\begin{array}{l}\text { CABG } 55 \% \text { vs } 58 \% \\
\text { CABG + valve } 12 \% \text { vs } 12 \% \\
\text { Isolated valve } 30 \% \text { vs } 25 \% \\
\text { Combined } 3 \% \text { vs } 5 \%\end{array}$ & CABG $75 \%$ vs $78 \%$ \\
\hline $\begin{array}{l}\text { Vancomycin } \\
\text { paste } \\
\text { composition }\end{array}$ & $\begin{array}{l}5 \mathrm{~mL} \text { of } 10 \% \text { calcium chloride; } \\
5000 \mathrm{IUs} \text { of topical thrombin } \\
\text { (bovine origin). } 0.6 \mathrm{~mL} \text { of the } \\
\text { resulting suspension with } 3 \mathrm{~mL} \\
\text { of PRP, and } 2 \mathrm{~g} \text { of vancomycin } \\
\text { hydrochloride powder }\end{array}$ & $\begin{array}{l}5 \text { or } 10 \mathrm{~g} \text { of powdered } \\
\text { vancomycin in a small amount } \\
\text { of sterile water }\end{array}$ & $\begin{array}{l}2.5 \mathrm{~g} \text { of powdered vancomycin } \\
\text { (Eli Lilly Inc, Indianapolis, } \\
\text { Ind) diluted in } 2 \mathrm{~mL} \text { of saline }\end{array}$ & $\begin{array}{l}1 \mathrm{~g} \text { of powdered absorbable } \\
\text { gelatin (Gelfoam, Upjohn Co., } \\
\text { Kalamazoo, Mich); topical } \\
\text { thrombin (1000 units/mL; } \\
\text { Armour Pharmaceutical Co., } \\
\text { Kankakee, Ill); } 250 \mathrm{mg} \\
\text { powdered vancomycin }\end{array}$ \\
\hline $\begin{array}{l}\text { Background IV } \\
\text { antibiotic } \\
\text { prophylaxis }\end{array}$ & $\begin{array}{l}\text { Started within } 1 \mathrm{~h} \text { of incision and } \\
\text { discontinued } 48 \mathrm{~h} \text { of surgery. } \\
\text { Before } 2006 \text { usually } \\
\text { vancomycin or ceftazidime. } \\
\text { Cefazolin in } 2006 \text { and } \\
\text { afterwards. }\end{array}$ & Routine preoperative & $\begin{array}{l}\text { s Cefazolin ( } 2 \mathrm{~g} \text { IV every } 8 \mathrm{~h}) \text { and } \\
\text { vancomycin }(1 \mathrm{~g} \text { IV every } 12 \mathrm{~h}) \\
\text { on induction of anesthetic and } \\
\text { continuing for } 48 \mathrm{~h} \text { after } \\
\text { surgery. }\end{array}$ & $\begin{array}{l}\text { Cefazolin; vancomycin in case of } \\
\text { penicillin allergy; continued for } \\
36 \mathrm{~h} \text { after surgery }\end{array}$ \\
\hline SWI definition & $\begin{array}{l}\text { SSWI: (1) suture granuloma or } \\
\text { suture reaction or wire } \\
\text { reaction; (2) bone click or } \\
\text { unstable bone; (3) skin } \\
\text { dehiscence or skin-only } \\
\text { superficial wound infection; (4) } \\
\text { deep tissue infection from the } \\
\text { subcutaneous to the bone but no } \\
\text { bone involvement; DSWI: (5) } \\
\text { infection including bone } \\
\text { involvement; (6) infection } \\
\text { including bone involvement } \\
\text { plus septicemia. }\end{array}$ & $\begin{array}{l}\text { DSWI: infection involving any or } \\
\text { all of the muscle, bone, or } \\
\text { mediastinum that occurred } \\
\text { within } 90 \mathrm{~d} \text { of the operation, } \\
\text { required operative intervention } \\
\text { (incision and drainage or re- } \\
\text { exploration), had positive } \\
\text { cultures if obtained, and the } \\
\text { patient was not receiving } \\
\text { antibiotics at the time of } \\
\text { sampling, and received } \\
\text { antibiotic treatment beyond } \\
\text { routine perioperative } \\
\text { prophylaxis. }\end{array}$ & $\begin{array}{l}\text { rDepths } 1 \text { and } 2 \text { were defined as a } \\
\text { superficial infectious process } \\
\text { limited to the subcuticular and } \\
\text { subcutaneous layers with no } \\
\text { involvement of the sternal } \\
\text { bone. Depths } 3 \text { and } 4 \text {, which } \\
\text { involved the sternal bone or } \\
\text { wires and collections beneath } \\
\text { the sternum, were considered } \\
\text { deep infections. }\{\end{array}$ & $\begin{array}{l}\text { DSWI: sternal or mediastinal } \\
\text { infections always necessitating } \\
\text { a major operation; SSWIs: no } \\
\text { sternal involvement. }\end{array}$ \\
\hline $\begin{array}{l}\text { Infection } \\
\text { assessment }\end{array}$ & $\begin{array}{l}\text { In hospital, during follow-up } \\
\text { office visits, and via telephone } \\
\text { calls for } 12 \mathrm{mo}\end{array}$ & Manual record review & $\begin{array}{l}\text { Infection only if above }+ \text { positive } \\
\text { culture for an organism was } \\
\text { obtained }\end{array}$ & \\
\hline BIMA & NR & NR & $\begin{array}{l}\text { At discretion of the operator; } 3 \% \\
\text { vs } 3 \%\end{array}$ & Three patients had BIMA grafts \\
\hline Male, $\%$ & 69.5 vs 66.8 & 64.0 vs $66.5 \ddagger$ & 68.9 vs 68.0 & $69.1 \%$ vs 66.8 \\
\hline Age, y & $64.9 \pm 11.7$ vs $64.1 \pm 11.6$ & NR & $65.7 \pm 11.6$ vs $65.9 \pm 12.7$ & 62.5 vs 62.0 \\
\hline BMI & NR & $28(22-36)$ vs $27(22-36) \ddagger$ & NR & NR \\
\hline Diabetes, $\%$ & 33.0 vs 34.7 & 27.1 vs 26.3 & 34 vs 33 & 21.1 vs 19.2 \\
\hline COPD & $16.1 \%$ vs $14.6 \%$ & $15.1 \%$ vs $13.2 \% \ddagger$ & $9 \%$ vs $11 \%$ & NR \\
\hline $\begin{array}{l}\text { Preoperative } \\
\text { NYHA III/IV }\end{array}$ & $41.1 \%$ vs $25.9 \% \ddagger$ & $36.0 \%$ vs $36.6 \% \ddagger$ & NR & NR \\
\hline $\begin{array}{l}\text { Nonelective } \\
\text { status }\end{array}$ & $44.5 \%$ vs $12.2 \% \ddagger$ & $31.2 \%$ vs $35.1 \% \ddagger$ & $58 \%$ vs $57 \%$ & NR \\
\hline
\end{tabular}


TABLE 1. Continued

\begin{tabular}{rllll}
\hline & \multicolumn{2}{c}{ Hamman and colleagues, } & & \multicolumn{2}{c}{ Vander Salm and colleagues, } \\
Study & $\mathbf{2 0 1 4}^{\mathrm{E8}}$ & Lander and colleagues, $\mathbf{2 0 1 6}^{\mathrm{E} 3}$ & Lazar and colleagues, 2014 $^{\text {5 }}$ & $\mathbf{1 9 8 9}^{\mathrm{E} 7}$ \\
\hline Follow-up & $12 \mathrm{mo}$ & $\begin{array}{l}90 \mathrm{~d} \text { for SWI } \\
5 \mathrm{y} \text { for death }\end{array}$ & $12 \mathrm{mo}$ & $1 \mathrm{mo}$ \\
& & & & \\
\hline
\end{tabular}

$R C T$, Randomized controlled trial; $N A$, not applicable; $C A B G$, coronary artery bypass grafting; $P R P$, platelet-rich plasma; $I V$, intravenous; $S W I$, sternal wound infection; SSWI, superficial sternal wound infection; $D S W I$, deep sternal wound infection; $N R$, not reported; BIMA, bilateral internal mammary artery; BMI, body mass index; COPD, chronic obstructive pulmonary disease; NYHA, New York Heart Association. *A logistic regression model was fit to estimate the likelihood of receiving the study intervention. Covariates included established risk factors identified by the Society of Thoracic Surgeons as well as other clinical and demographic factors; estimates from the resulting propensity model were then used to adjust the effect of the study intervention on DSWI in a logistic regression that used Firth's penalized maximum likelihood method. $\dagger$ A total of 444 propensitymatched pairs: The variables used for propensity score matching included ejection fraction, age, heart failure, peripheral vascular disease, endocarditis, diabetes, type of surgery, urgency of surgery, smoking, previous myocardial infarction, preoperative steroids, serum creatinine, weight, crossclamp time, and cardiopulmonary bypass time. $\ddagger$ Patient characteristics that were statistically different. §According to Mangram and colleagues.

A Preferred Reporting Items for Systematic Reviews and meta-analyses flow diagram describing the study selection process along with reasons for exclusion is presented in Figure E1. The initial search yielded 70 records; after exclusion of reports not pertinent to the design of the meta-analysis, ${ }^{\mathrm{E} 1, \mathrm{E} 2, \mathrm{E} 5, \mathrm{E} 6} 4$ studies, 5 , E3,E8 (among them 1 randomized controlled trial ${ }^{\mathrm{E} 7}$ ) remained, which collectively enrolled 20,039 patients; 6843 received topically administered vancomycin intraoperatively, whereas 13,196 served as a control group. Baseline characteristics of included studies as well as endpoint definitions are listed in Table 1.

Vancomycin dose varied across the studies and ranged from $250 \mathrm{mg}^{\mathrm{E} 7}$ to 5 to $10 \mathrm{~g}$. ${ }^{\mathrm{E} 3}$ In one study, vancomycin paste contained platelet-rich plasma ${ }^{\mathrm{E} 7}$ and in 2 thrombin as well. ${ }^{\mathrm{E}, \mathrm{E} 8}$ By visual inspection of funnel plot constructed for the endpoint SWI, there was no sign of publication bias for all but one study ${ }^{\mathrm{E} 3}$ (Figure E2). Sources of potential bias are listed in Table E1. Topically

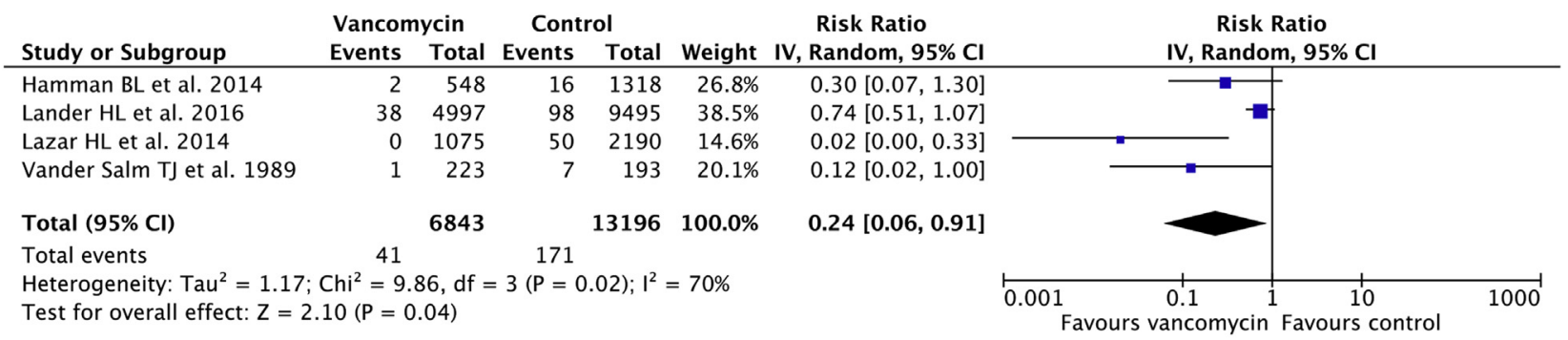

A

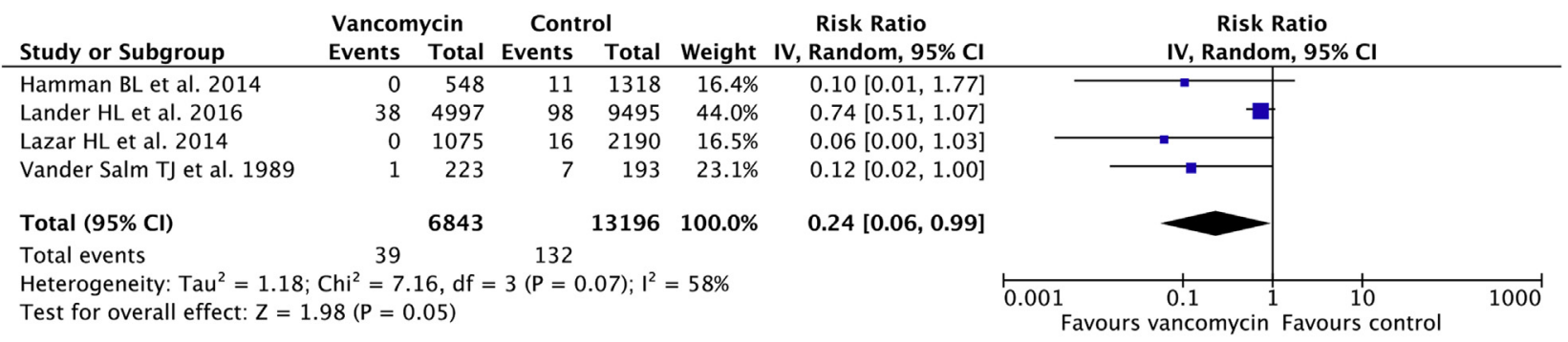

B

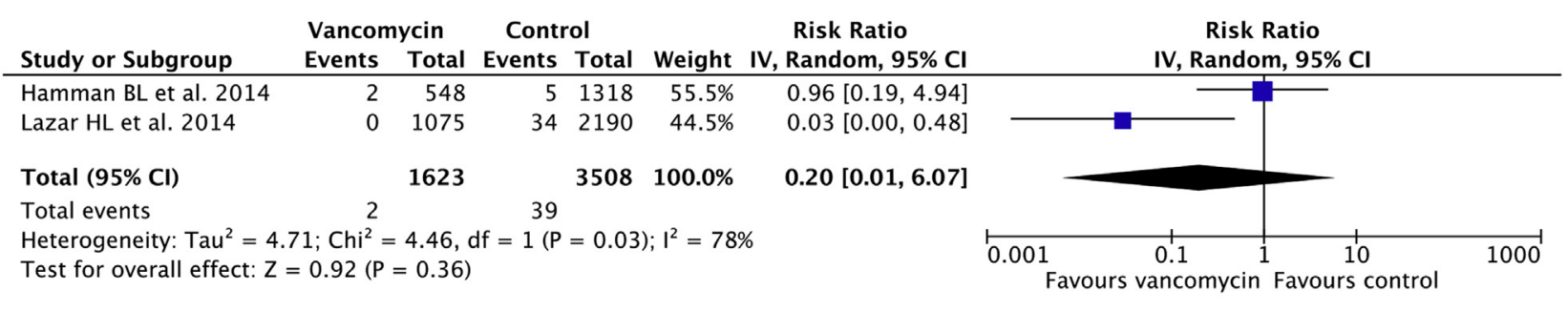

FIGURE 1. A, Forest plot of the comparison between topically administered vancomycin for the prevention of any sternal wound infections: B, deep sternal wound infections and (C) superficial sternal wound infections compared with control group. Risk ratios and $95 \% \mathrm{CIs}$ shown. $I V$, Inverse variance; $C I$, confidence interval. 
administered vancomycin was associated with a $76 \%$ significant risk reduction of any SWI as compared with the control group: RR $(95 \% \mathrm{CI}): 0.24(0.06-0.91) P=.04$; $I^{2}=70 \%$; the corresponding event rates were $0.60 \%(41 /$ $6843)$ and $1.29 \%(171 / 13,196)$ in the vancomycin and control groups, respectively (Figure 1,A). A sensitivity analysis performed by eliminating a single study, one at a time, and repeating the calculations, confirmed the direction and magnitude of the estimates (Figure E3). Similar statistically significant risk reduction was demonstrated when analysis was restricted to DSWI: topical vancomycin reduced the risk of DSWI by 76\%: RR (95\% CI): 0.24 (0.06-0.99) $P=.05 ; I^{2}=58 \%$ with corresponding event rates of $0.57 \%(39 / 6843)$ and $1.00 \%(132 / 13,196)$ for vancomycin and control groups, respectively (Figure 1, B). Two studies only ${ }^{\mathrm{E} 3, \mathrm{E} 5}(\mathrm{~N}=5131)$ provided data on the incidence of SSWIs: although SSWIs occurred in 2 patients receiving topical vancomycin $(0.12 \%)$ and 39 patients in the control group $(1.11 \%)$, in random effects model, this difference was not significant: RR (95\% CI): 0.20 (0.016.07) $P=.36 ; I^{2}=78 \%$ (Figure $1, C$ ).

In the largest study to date, Lander and colleagues ${ }^{\mathrm{E} 3}$ demonstrated that vancomycin paste did not reduce the incidence of DSWI after cardiac operations. In the current meta-analysis, this particular study was found to be the source of substantial heterogeneity in the analysis of SWIs, the reason being, apart from unbalanced baseline characteristics of the patients, certain methodologic flaws: (1) the study covers a 12-year period with indisputable changes involving perioperative antibiotics, glycemic control, and sternal closure techniques; (2) nonreporting of SSWIs; (3) exclusion, by design, of patients with infective endocarditis and receiving heart transplant, given their likelihood to gain most benefit from vancomycin paste; (4) exclusion of 9 patients who developed DSWI at 3 months after surgery and most importantly: and (5) indeed, vancomycin paste was used only in $25 \%$ of patients in the first 7 years (2321/9413 from the 2003 to 2010 time period) with $1.29 \%$ rate of DSWI (121 DSWI/9413 patients); in the second time period (2011-2015), vancomycin paste was used in $53 \%$ of patients (2676/5079 patients) with a rate of DSWI cut nearly 5 -fold $(0.29 \%$ [15 DSWI/5079 patients]). This, in turn, suggests strong influence of factors other than topical vancomycin must have driven the results towards null.
In contrast, in a second largest (1075 vs 2190 patients) study group study by Lazar and colleagues, ${ }^{5}$ topical vancomycin applied to the sternal edges, in conjunction with perioperative antibiotics and strict glycemic control, eliminated SSWIs $(0 \%$ vs $1.6 \% ; P<.0001)$, DSWIs $(0 \%$ vs $0.7 \%$; $P=.005)$, and any type of SWIs $(0 \%$ vs $2.2 \%$; $P<.0001)$ in unselected consecutive cardiac surgical patients. Ease and applicability of vancomycin paste needs to be further mentioned; after mixing $2 \mathrm{~g}$ of vancomycin powder with a very small amount of saline $(2 \mathrm{~mL})$, it forms a wax much like bone wax that is applied to the cut edges of the sternal halves either (1) immediately after sternotomy ${ }^{\mathrm{E} 2}$ or (2) when the sternal wires are in place just before sternal approximation. $^{5}$

In conclusion, our results confirm the effectiveness of vancomycin in the discussed clinical scenario, thus supporting the recommendations of the recent expert consensus review on prevention and management of sternal wound infections. $^{2}$ Despite the fact that this meta-analysis is limited mainly to observational studies, it should help to guide decision-making regarding the intraoperative topical antibiotic prophylaxis of SWI, and in particular the vancomycin, until the results of upcoming research (eg, Topical Use of Vancomycin in Reducing Sternal Wound Infection in Cardiac Surgery [SWI Trial] NCT02374853) are available.

\section{References}

1. Toumpoulis IK, Anagnostopoulos CE, Derose JJ Jr, Swistel DG. The impact of deep sternal wound infection on long-term survival after coronary artery bypass grafting. Chest. 2005; 127:464-71.

2. Lazar HL, Salm TV, Engelman R, Orgill D, Gordon S. Prevention and management of sternal wound infections. J Thorac Cardiovasc Surg. 2016;152: 962-72.

3. Kowalewski M, Pawliszak W, Zaborowska K, Navarese EP, Szwed KA, Kowalkowska ME, et al. Gentamicin-collagen sponge reduces the risk of sternal wound infections after heart surgery: meta-analysis. J Thorac Cardiovasc Surg. 2015;149:1631-40.e6.

4. Kowalewski M, Pawliszak W, Zaborowska K, Navarese EP, Szwed KA, Kowalkowska ME, et al. Implantable gentamicin-collagen sponge and the risk of sternal wound infections after heart surgery. An updated meta-analysis. Presented at 30th EACTS Annual Meeting, Barcelona, Spain, 1-5 October 2016. Available at: http:// medialibrary.eacts.cyim.com/mediatheque/media.aspx?mediaId=18321\&channel =10233. Accessed January 3, 2016.

5. Lazar HL, Ketchedjian A, Haime M, Karlson K, Cabral H. Topical vancomycin in combination with perioperative antibiotics and tight glycemic control helps to eliminate sternal wound infections. J Thorac Cardiovasc Surg. 2014; $148: 1035-40$.

6. Mangram AJ, Horan TC, Pearson ML, Silver LC, Jarvis WR. Guideline for prevention of surgical site infection, 1999. Hospital Infection Control Practices Advisory Committee. Infect Control Hosp Epidemiol. 1999;20:250-78. 


\section{E-References}

E1. Lazar HL, Barlam T, Cabral H. The effect of topical vancomycin applied to sternotomy incisions on postoperative serum vancomycin levels. J Card Surg. 2011; 26:461-5.

E2. Arruda MV, Braile DM, Joaquim MR, Suzuki FA, Alves RH. The use of the vancomycin paste for sternal hemostasis and mediastinitis prophylaxis. Rev Bras Cir Cardiovasc. 2008;23:35-9.

E3. Lander HL, Ejiofor JI, McGurk S, Tsuyoshi K, Shekar P, Body SC. Vancomycin paste does not reduce the incidence of deep sternal wound infection after cardiac operations. Ann Thorac Surg. 2017;103:497-503.

E4. Liberati A, Altman DG, Tetzlaff J, Mulrow C, Gøtzsche PC, Ioannidis JP, et al. The PRISMA statement for reporting systematic reviews and meta-analyses of studies that evaluate health care interventions. Ann Intern Med. 2009;151: W65-94.
E5. Kieser TM, Rose MS, Aluthman U, Montgomery M, Louie T, Belenkie I. Toward zero: deep sternal wound infection after 1001 consecutive coronary artery bypass procedures using arterial grafts: implications for diabetic patients. J Thorac Cardiovasc Surg. 2014;148:1887-95.

E6. Oakely RE, Nimer KA, Bukhari E. Is the use of topical vancomycin to prevent mediastinitis after cardiac surgery justified? J Thorac Cardiovasc Surg. 2000; 119:190-1.

E7. Vander Salm TJ, Okike ON, Pasque MK, Pezzella AT, Lew R, Traina V, et al. Reduction of sternal infection by application of topical vancomycin. J Thorac Cardiovasc Surg. 1989;98:618-22.

E8. Hamman BL, Stout LY, Theologes TT, Sass DM, da Graca B, Filardo G, et al. Relation between topical application of platelet-rich plasma and vancomycin and severe deep sternal wound infections after a first median sternotomy. Am J Cardiol. 2014;113:1415-9.
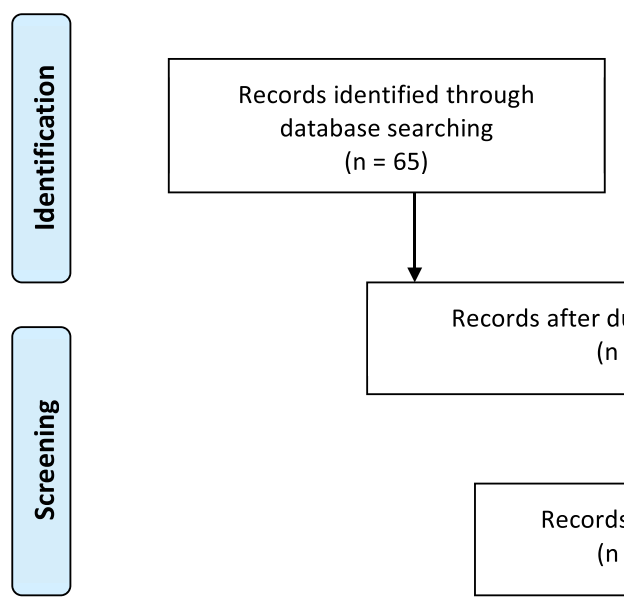
$(n=65)$
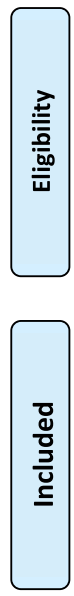

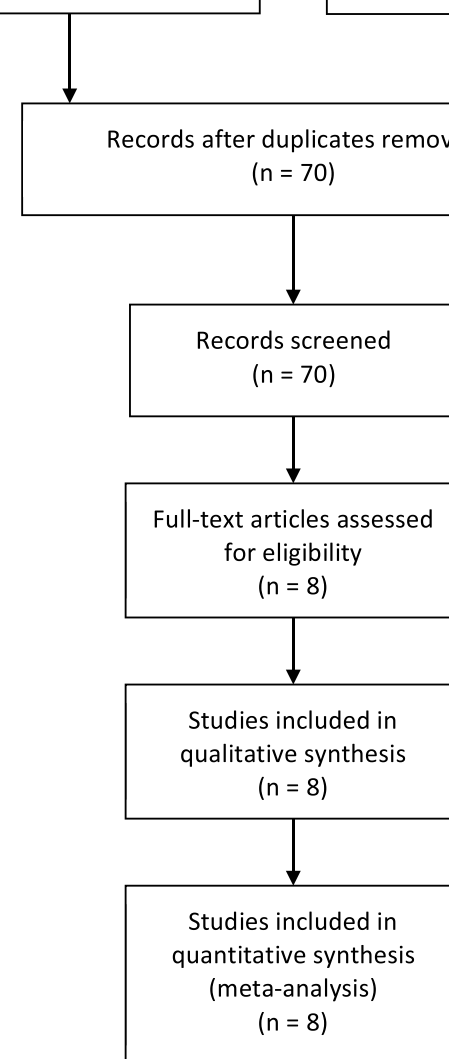

Additional records identified through other sources $(n=14)$

tudies included in

ative synthesis

$(n=8)$

FIGURE E1. Preferred Reporting Items for Systematic Reviews and meta-analyses flow diagram describing the selection process of studies to be included and also reasons for exclusion of other studies. 


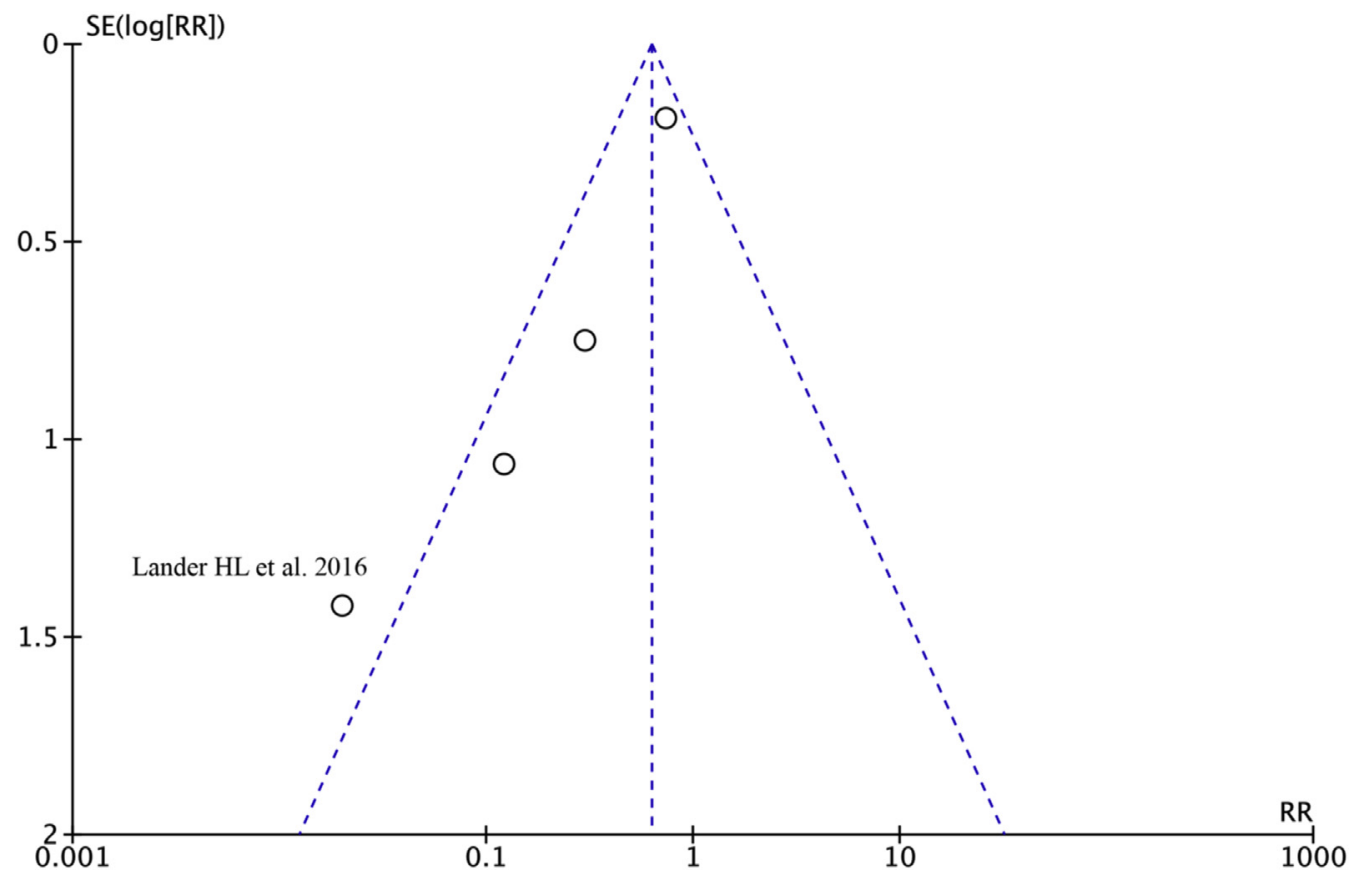

FIGURE E2. Publication bias analysis. $S E$, Standard error; $R R$, risk ratio.

Study name

Hamman BL et al. 2014

Lander HL et al. 2016

Lazar HL et al. 2014

Vander Salm TJ et al. 1989
Statistics with study removed

$\begin{array}{llccc}\text { Point } & \begin{array}{c}\text { Lower } \\ \text { limit }\end{array} & \begin{array}{c}\text { Upper } \\ \text { limit }\end{array} & \text { Z-Value } & \text { p-Value } \\ 0.172 & 0.021 & 1.408 & -1.641 & 0.101 \\ 0.132 & 0.033 & 0.532 & -2.847 & 0.004 \\ 0.438 & 0.166 & 1.155 & -1.668 & 0.095 \\ 0.276 & 0.059 & 1.295 & -1.632 & 0.103 \\ 0.239 & 0.063 & 0.910 & -2.098 & 0.036\end{array}$

Risk ratio $(95 \%$ Cl)

with study removed
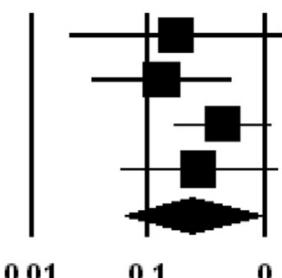

0.1

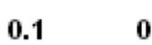

$0 \quad 10$

Favour: control

FIGURE E3. Sensitivity analysis performed by deleting one study at a time and repeating the calculations. CIs, Confidence intervals. 
TABLE E1. Risk of bias analysis

\begin{tabular}{|c|c|c|c|c|}
\hline Study & $\begin{array}{c}\text { Hamman and colleagues, } \\
\mathbf{2 0 1 4}^{\mathrm{E} 8}\end{array}$ & $\begin{array}{c}\text { Lander and colleagues, } \\
2^{2016^{\mathrm{E} 3}}\end{array}$ & $\begin{array}{c}\text { Lazar and colleagues, } \\
2014^{5}\end{array}$ & $\begin{array}{l}\text { Vander Salm and } \\
\text { colleagues, } \text { 1989 }^{\mathrm{E} 7}\end{array}$ \\
\hline Random sequence generation & NA & NA & NA & Low risk of bias \\
\hline Allocation concealment & Unclear risk of bias & Unclear risk of bias & Unclear risk of bias & Unclear risk of bias \\
\hline Participant blinding & Unclear risk of bias & Unclear risk of bias & Unclear risk of bias & Unclear risk of bias \\
\hline $\begin{array}{l}\text { Outcomes assessment } \\
\text { blinding }\end{array}$ & High risk of bias & High risk of bias & High risk of bias & High risk of bias \\
\hline Incomplete outcome & Low risk of bias & Unclear risk of bias & Low risk of bias & Unclear risk of bias \\
\hline Selective reporting & Low risk of bias & Low risk of bias & Low risk of bias & Low risk of bias \\
\hline Other bias & $\begin{array}{l}\text { Significantly less CABG in } \\
\text { the vancomycin arm }\end{array}$ & $\begin{array}{l}\text { Infections analyzed up to } \\
90 \mathrm{~d} \text { postoperatively }\end{array}$ & - & $\begin{array}{l}\text { Vancomycin paste more often } \\
\text { in redo operations }\end{array}$ \\
\hline
\end{tabular}

$N A$, Not applicable; $C A B G$, coronary artery bypass grafting. 